\title{
GPR APPLIED TO RIGID PAVEMENT FROM SANTOS DUMONT AIRPORT, RJ
}

\author{
Welitom Rodrigues Borges ${ }^{1}$, Luís Anselmo da Silva², Luciano Soares da Cunha ${ }^{1}$, \\ Raimundo Mariano Gomes Castelo Branco ${ }^{3}$ and Márcio Muniz de Farias ${ }^{4}$
}

\begin{abstract}
This paper presents the results of a research performed by using Ground Penetration Radar (GPR) to evaluate the structure of the rigid pavement of Santos Dumont Airport in Rio de Janeiro, Brazil. The GPR data profiles were acquired with 250 and $700 \mathrm{MHz}$ shielded antennas. The geophysical investigation was performed along of 6 profiles, totaling 1432 meters of GPR sections. For calibration of the speed of propagation of electromagnetic wave were drilled three boreholes until the depth of $1.8 \mathrm{~m}$. The results of GPR allowed the precise delineation of reflectors related to geotechnical interfaces (pavement thickness - concrete slab and macadam) and geological (sand/embankment soil), showing the efficiency of this method in this case study.
\end{abstract}

Keywords: GPR, concrete, rigid pavement, Santos Dumont Airport.

RESUMO. Este trabalho apresenta o resultado de uma pesquisa desenvolvida usando Ground Penetrating Radar (GPR) para avaliar a estrutura do pavimento rígido do pátio de manobras de aeronaves do Aeroporto Santos Dumont, no Rio de Janeiro, Brasil. Para isso foram usadas antenas blindadas com frequências de $250 \mathrm{MHz}$ e de $700 \mathrm{MHz}$. Os dados de GPR foram adquiridos no modo common offset, ao longo de 6 perfis que totalizam 1432 metros de investigação. Para a calibração da velocidade de propagação da onda eletromagnética foram executados três furos de sondagem até a profundidade de 1,8 m. Os resultados de GPR possibilitaram 0 delineamento preciso de refletores relacionados a interfaces geotécnicas (espessura do pavimento - revestimento de concreto e do macadame) e geológicas (areia/aterro com entulho), mostrando a eficiência da aplicação deste método neste estudo de caso.

Palavras-chave: GPR, concreto, pavimento rígido, Aeroporto Santos Dumont.

\footnotetext{
${ }_{1}^{1}$ Universidade de Brasília (UnB), Instituto de Geociências (IG), Campus Darcy Ribeiro, Asa Norte, 79910-900 Brasília, DF, Brazil. Phone: +55(61) 3107-6987/3107-6994 - E-mails: welitom@unb.br; lucianosc@unb.br 2 Instituto Federal de Educação, Ciência e Tecnologia de Mato Grosso (IFMT), Rua Zulmira Canavarros, 95, Centro, 78005-200 Cuiabá, MT, Brazil. Phone: +55(65) 3314-3585 - E-mail: luis.anselmo@cba.ifmt.edu.br

3 Universidade Federal do Ceará (UFC), Laboratório de Geofísica de Prospecção e Sensoriamento Remoto (LGPSR), Campus do Pici, 60455-760 Fortaleza, CE, Brazil. Phone: +55(85) 3288-9870 - E-mail: marianogcb@gmail.com

${ }^{4}$ Universidade de Brasília (UnB), Faculdade de Tecnologia (FT), Departamento de Engenharia Civil, Campus Darcy Ribeiro, Asa Norte, 79910-900 Brasília, DF, Brazil. Phone: +55(61) 3107-0964 - E-mail: muniz@unb.br
} 


\section{INTRODUCTION}

The continued Brazilian economic development requires investment in terrestrial, nautical, and aviation infrastructure to maintain its balance. Regarding aviation, Empresa Brasileira de Infraestrutura Aeroportuária (INFRAERO) exposes a critical overview for Brazilian airports and emphasizes the necessity and urgency of upkeep, reform and expansion of its physical infrastructure. The landing runway, maneuvering areas and parking lots of aircrafts are essential for the operation and function of an airport (Oliveira \& Nobre Jr., 2008).

In Brazil, the main problem with aerial transportation is insufficient landings, runways, and maneuvering areas for aircraft. The high impact loads resulting from takeoff and landing of the aircraft are supported by an appropriate structure of the pavement, which transmits a compatible stress resistance to subgrade. Although there are significant differences in the cross sections of road pavement and airport runways (Yoder \& Witczak, 1975), the pavement can be generally defined as a multilayer structure of finite thickness, built on the end surface of earthworks designed, technically and economically, to resist stress arising from vehicular traffic and weather, and to provide better transit conditions to users with comfort, economy, and safety (Bernucci et al., 2006).

To fulfill its functions of safety, comfort, and to also resist horizontal shear stress, pavement must have its superficial layer consisting of cohesive material (TAC, 1997). Pavement is classified basically into flexible and rigid.

The flexible pavement are those wherein the surface is comprised of a mixture consisting of essential aggregates and asphalt binders capable of resisting the traffic directly to the actions and transmit them at a reduced force to the lower layers, which are usually made of granular bases and sub-bases. Since the rigid pavement is constituted by Portland's cement concrete slabs which has a high rigidity in relation to lower layers and therefore absorbs virtually all shocks from the applied load (DNIT, 2006). Thus, in rigid pavement, the concrete slab is at the same time the base and cover layers, which typically sits on a layer of granular sub-base or roller compacted concrete.

The aircraft's landing and takeoff pavement are commonly built with flexible pavement because of the best tire to pavement grip and greater rolling comfort. The shunting yard and parking of aircraft is constructed with rigid pavement due to the rheological behavior of asphalt layers, which may have increased permanent deformation when subjected to long static charges.

The knowledge of pavement structure and the deformation of the surface layer of aircraft pavement is very important for the maintenance and rehabilitation against premature wear, such as fatigue of tarmac materials due to the excess load, bad design, or inadequate construction (Shahin, 1994). Only a precise and efficient evaluation allows the creation of an expressive database, to provide management with a proper support of the tarmac.

The knowledge of the prior pavement structure requires a good report at the end of construction ("as built"), as well as a permanent and detailed record of all interventions done on the pavement during its service life. Unfortunately this record is not available in most cases and it is necessary to resort to direct or indirect methods of sampling to determine the composition and thickness of the pavement layers.

On direct sampling methods, you must dig a trench or extract a sample of the pavement (core) to measure the thickness of layers. Although this method provides an accurate measurement, it is destructive, time consuming, and does not provide a continuous representation of the thickness of layers, since it is a specific inquiry. With indirect methods of sampling the physical parameters can be obtained on the surface in places where there are restrictions for excavation and drilling. The main indirect method of investigation is geophysics which uses the physical properties to study the environment. According to Telford et al. (1990), there are various geophysical methods that allow the detection of subsurface structures (gravimetry, magnetometry, radiometry, electromagnetometry, seismic and resistivity), however, for the study of pavement, the ground penetrating radar (GPR) was highlighted in recent decades (Hugenschmidt, 2002; Lahouar \& Al-Qadi, 2008).

In Brazil, studies realized by Lima-Filho et al. (2004) and Gomes (2008) used GPR to identify causes of deformation and to evaluate the pavement structure on landing, takeoff, runway and maneuvering areas of aircraft at airports. Gomes (2008) noted that non-destructive methods do not completely eliminate the use of destructive methods, which apply in a complementary way and in smaller numbers and are markedly more expensive than nondestructive. In his research Gomes (2008) concluded that joint and systemically in both devices implementing the Falling Weight Deflectometer (FWD) and GPR is a valuable tool for managing pavement, to get to know its structure.

Work performed by Barrile \& Pucinotti (2005), Hugenschmidt \& Mastrangelo (2006), Loizos \& Plati (2007), Lahouar \& Al-Qadi (2008) and Chang et al. (2009), show that GPR is a method which enables us to understand many aspects of the structural elements investigated in the evaluation of hard surfaces, such as thickness, homogeneity, defects, presence and number of longitudinal and transverse steelbars.

This work aims to show the efficiency of the use of GPR, associated with conventional methods, the investigation of the structure of rigid pavement Patio Maneuvering Aircraft, the Santos Dumont Airport in Rio de Janeiro/RJ. 


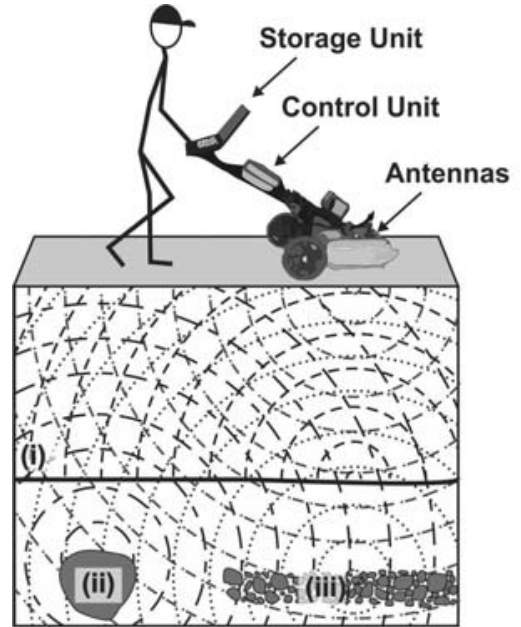

(a)

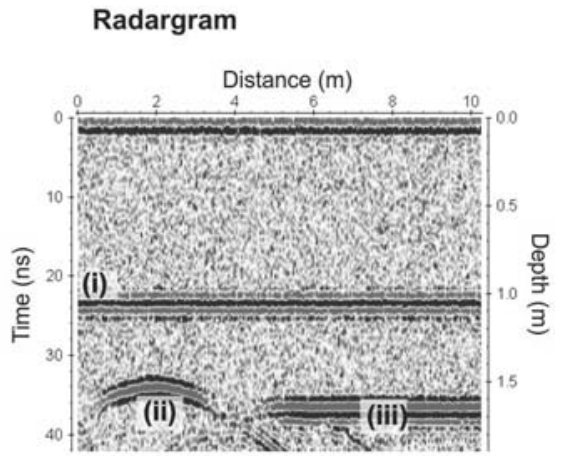

(b)
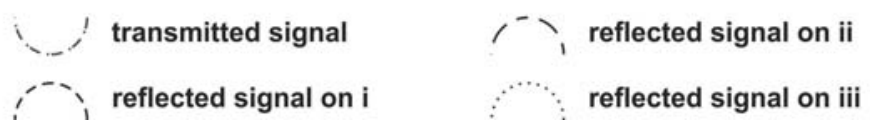

Figure 1 - Schematic diagram of the GPR data acquisition process (a) and radargram (b).

\section{METHODOLOGY}

The ground penetrating radar (GPR) is the general term applied to the geophysical method that uses radio waves, typically in the frequency range 10-2600 $\mathrm{MHz}$ to map geological structure and objects buried in the soil (Annan, 2001).

In this method the electromagnetic waves are radiated into the subsurface through a transmitting antenna. The contrast between the electrical properties of the subsurface cause the signal to be reflected back to the surface and continue to spread. This reflected signal is received by a receiving antenna and recorded and stored in a control unit. The continuous collection of this data along a surface enables the lateral stacking traits comprised of one radargram, representing a high resolution image of the subsurface (Fig. 1).

The investigated area was the aircraft maneuvering runway of Santos Dumont Airport, located in the Plaza Senador Salgado Filho, downtown of Rio de Janeiro/RJ (Fig. 2).

For the GPR data acquisition used the equipment Detector Duo (Ingegneria Dei Sistemi - IDS), which consists of three modules interconnected by cables. The first module consists of a set of shielded antennas (central frequency of $250 \mathrm{MHz}$ and $700 \mathrm{MHz}$ ); the second module by a control unit; and the third module comprises a data storage unit (Fig. 3).

The data acquisition parameters were: spacing between the traces of $2 \mathrm{~cm}$; time window of $64 \mathrm{~ns}$; 256 samples per trace and temporal sampling interval of $0.25 \mathrm{~ns}$.
Data were acquired over 6 lines named L1, L2, L3, L4, L5 and L6 (Fig. 4). Lines 2 and 6 were segmented into smaller lines of approximately 100 meters, depending on the activities in the aircraft maneuver runway during data acquisition, thus being named in L2A, L2B, L2C, L2D, L2E and L2F (L2) and as L6A, L6B, L6C, L6D, L6E and L6F (L6).

\section{RESULTS}

The electromagnetic velocity of each geotechnical interface was obtained with the aid of information extracted from 4 boreholes. From the survey it was possible to identify materials and the following layers: coating/concrete based on Portland cement board; sub-base in macadam (stone hand and stone powder); natural subgrade soil (fine to medium sand or silty sand). It also determined thicknesses of these layers in the survey region, thus allowing to correlate reflectors with the geotechnical and/or geological interfaces, given that, knowing the actual depth of these reflectors as well as related, we obtain the interval velocity of propagation of the wave the electromagnetic environment $\left(V_{i}\right)$, using the equation of the transit time of a wave where the incidence of it is perpendicular to the reflector (zero offset section) according to (Eq. 1).

$$
V_{i}=\frac{2 z_{i}}{t_{i}}
$$

where $z$ is the layer thickness, and $t$ is the double transit time of electromagnetic wave in the subsurface. 


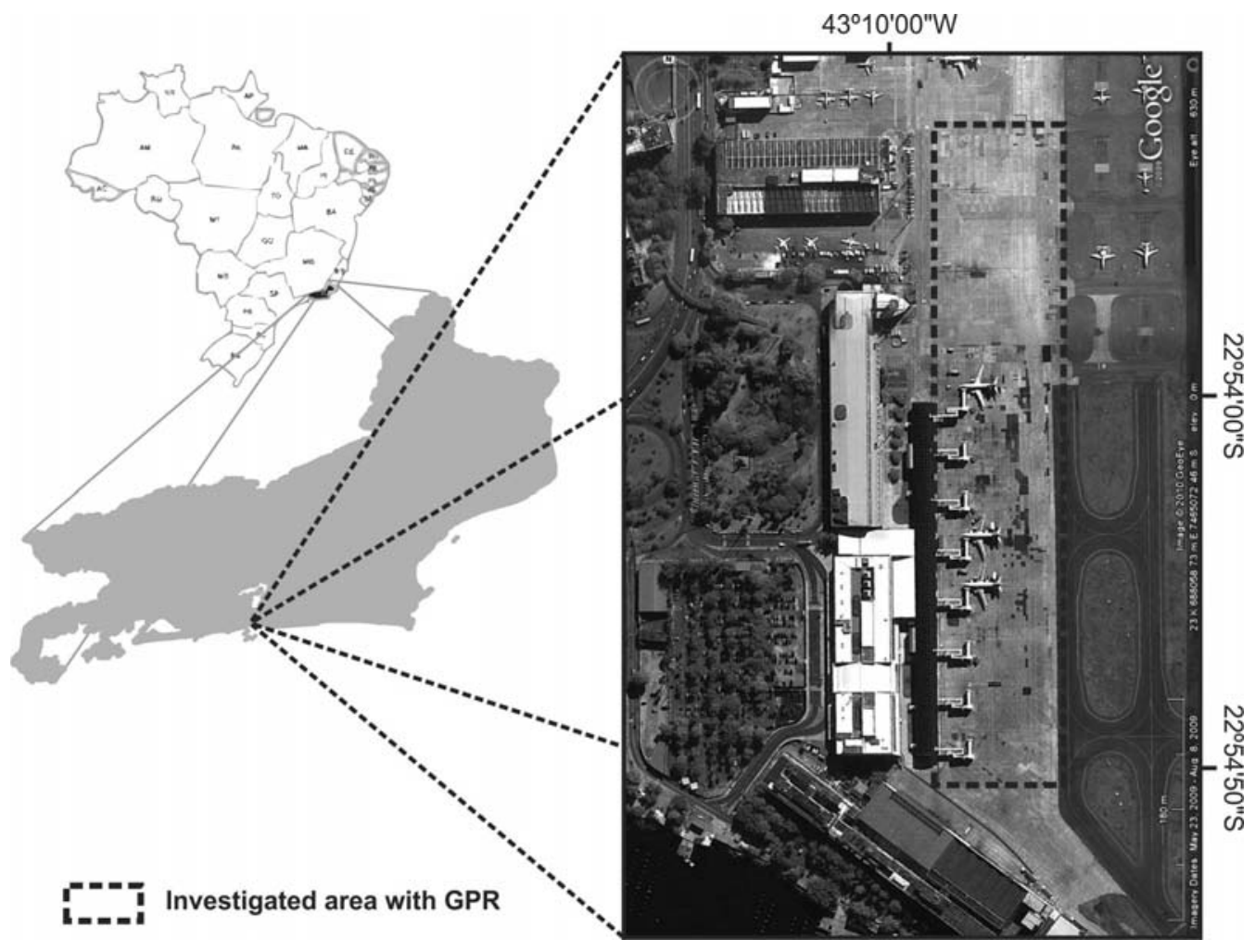

Figure 2 - Location of investigated area with GPR at Santos Dumond Airport, Rio de Janeiro/RJ.
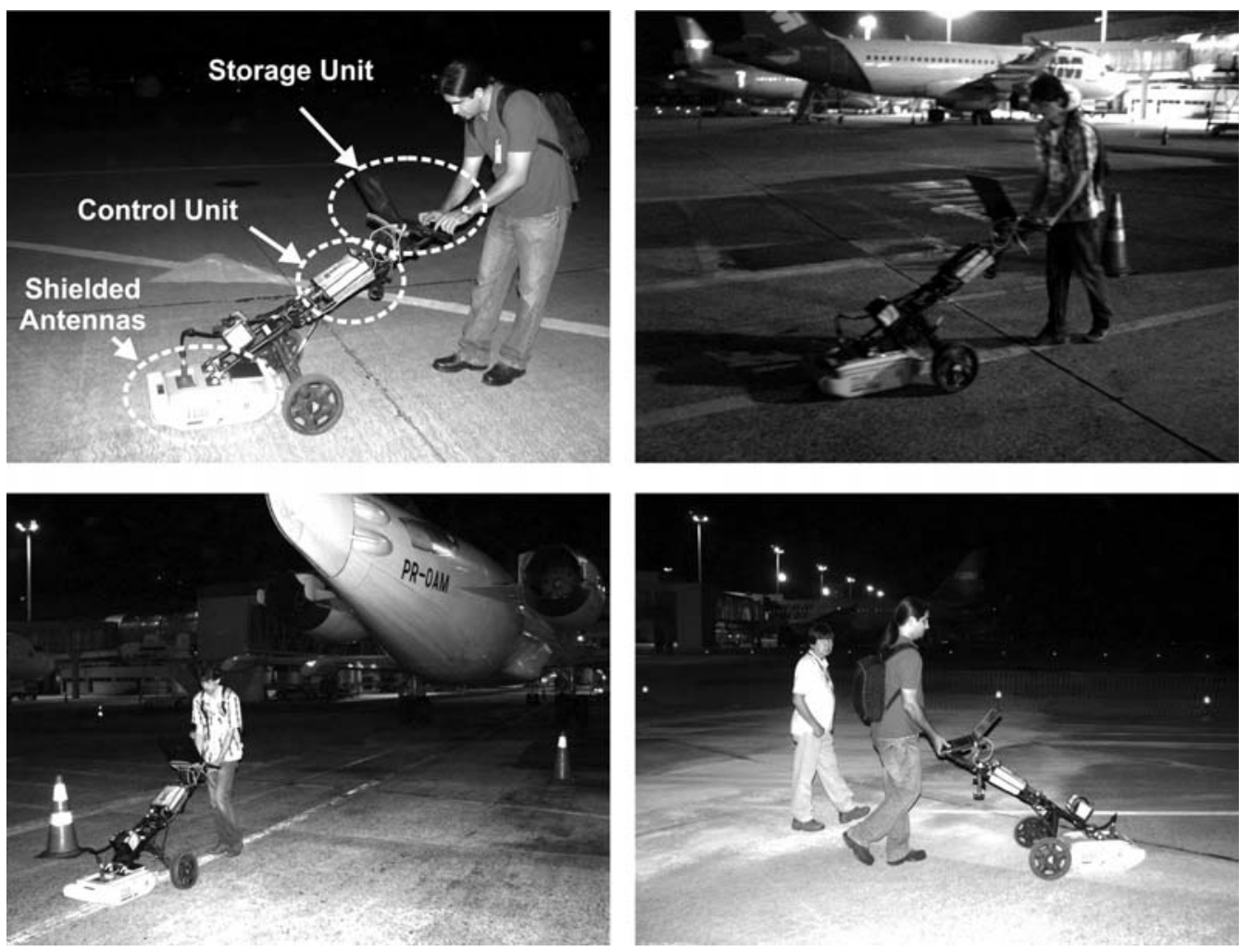

Figure 3 - Photos show the GPR data acquisition in part of the Santos Dumond Airport, Rio de Janeiro/RJ. 


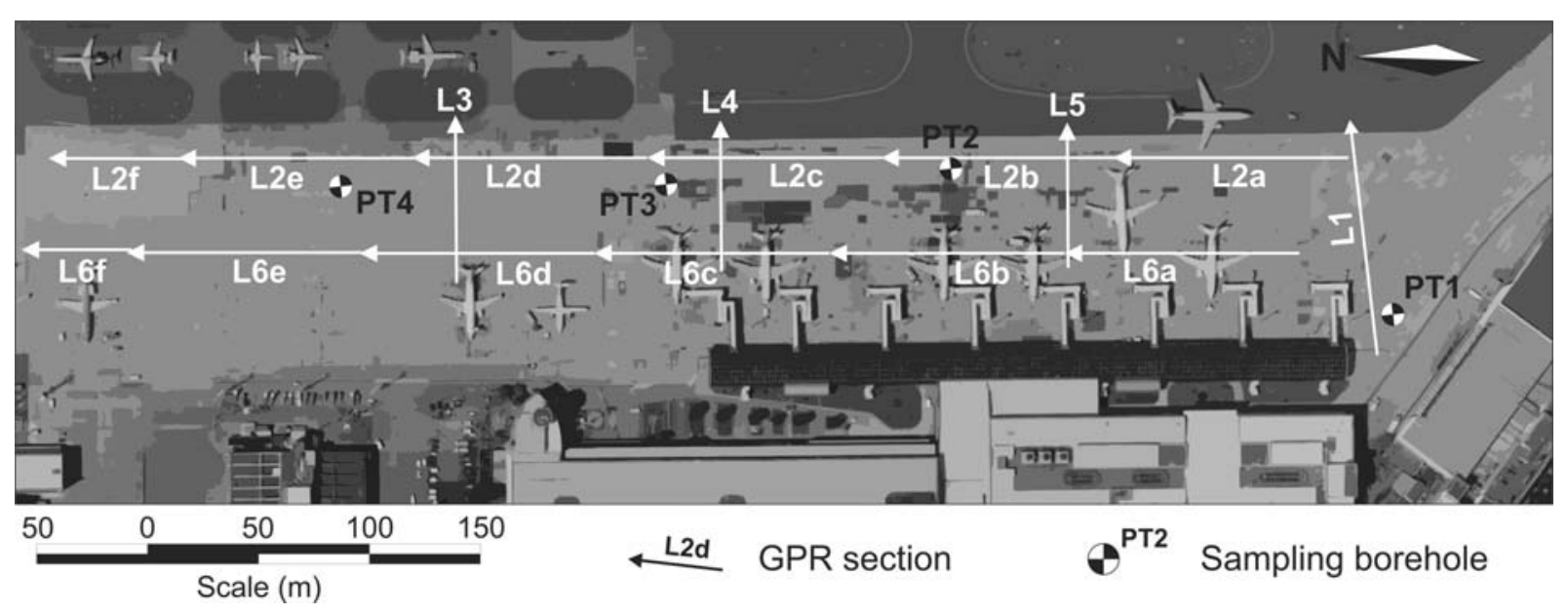

Figure 4 - Sketch with the position of the GPR profiles and boreholes sampling conducted in the Santos Dumond Airport, Rio de Janeiro/RJ.

Table 1 - List of thicknesses, transit time of electromagnetic wave and velocities of geotechnical interfaces found in the boreholes and correlated with the GPR data.

\begin{tabular}{|c|c|c|c|c|c|c|}
\hline \multirow[b]{3}{*}{ Borehole } & \multicolumn{6}{|c|}{ Layer } \\
\hline & \multicolumn{3}{|c|}{ Concrete } & \multicolumn{3}{|c|}{ Sub-base } \\
\hline & $\begin{array}{c}\text { Thickness } \\
\text { (m) }\end{array}$ & $\begin{array}{c}\text { Double Time of } \\
\text { reflection on } \\
\text { layer (ns) }\end{array}$ & $\begin{array}{c}\text { Velocity } \\
\text { (m/ns) }\end{array}$ & $\begin{array}{c}\text { Thickness } \\
\text { (m) }\end{array}$ & $\begin{array}{c}\text { Double Time of } \\
\text { reflection on } \\
\text { layer (ns) }\end{array}$ & $\begin{array}{c}\text { Velocity } \\
\text { (m/ns) }\end{array}$ \\
\hline $\mathrm{PTO1}^{(1)}$ & 0.20 & 4.82 & 0.083 & 0.31 & 10.50 & 0.109 \\
\hline PT02 (1) & 0.23 & 5.60 & 0.082 & 0.57 & 16.33 & 0.106 \\
\hline PT03 ${ }^{(2)}$ & 0.27 & 6.48 & 0.083 & 0.38 & 14.90 & 0.090 \\
\hline $\mathrm{PTO4}^{(2)}$ & 0.28 & 6.91 & 0.081 & 0.32 & 13.80 & 0.093 \\
\hline
\end{tabular}

The velocities obtained for materials were: $0.082 \mathrm{~m} / \mathrm{ns}$ for concrete, $0.1075 \mathrm{~m} / \mathrm{ns}$ for the macadam, and $0.0915 \mathrm{~m} / \mathrm{ns}$ for the gravel. Depending on the speed difference found for the macadam and the stone powder $(0.016 \mathrm{~m} / \mathrm{s})$, and the similarity between the patterns of reflections of these layers, a propagation speed of electromagnetic wave of $0.1 \mathrm{~m} / \mathrm{s}$ was used for both layers. As for the concrete a velocity conversion time to depth of $0.082 \mathrm{~m} / \mathrm{ns}$. Table 1 summarizes the values of layer thickness, as well as the times and the propagation velocities correlated to data in different boreholes.

\section{DISCUSSION}

By correlating boreholes, with reflectors identified on GPR radargrams (Fig. 5) it was possible to identify the main geological interfaces, geotechnical structures and various interferences present in the area of lines of data acquisition. Throughout the mapped area distinct patterns of reflection were observed in GPR sections which can be related to different types of materials.
Continuous reflectors represent the geological and/or geotechnical interfaces on site ground (concrete slab, macadam and gravel bases and pack the landfill subgrade). These reflectors are commonly straight, which may present as continuous subhorizontal or incline correlated with textural and compositional variations of the materials (Fig. 6).

The point reflectors, characterized by hyperbolic reflections (Fig. 7), may be related mostly to interference buried in the subsurface. Such features can be found throughout the extent of the area of clear and striking shape and at different depths from representing various types of pipes (gallery rainwater) to blocks of rocks.

After the correlation of continuous reflectors with geotechnical interfaces was realized an interpretation using REFLEXW software (Sandmeier, 2011), with the tools picking and layer show was held. The picking allows you to select each reflector related to geotechnical and/or geological interfaces, allowing the layers to sort by speed variation. On the other hand the layer show tool 

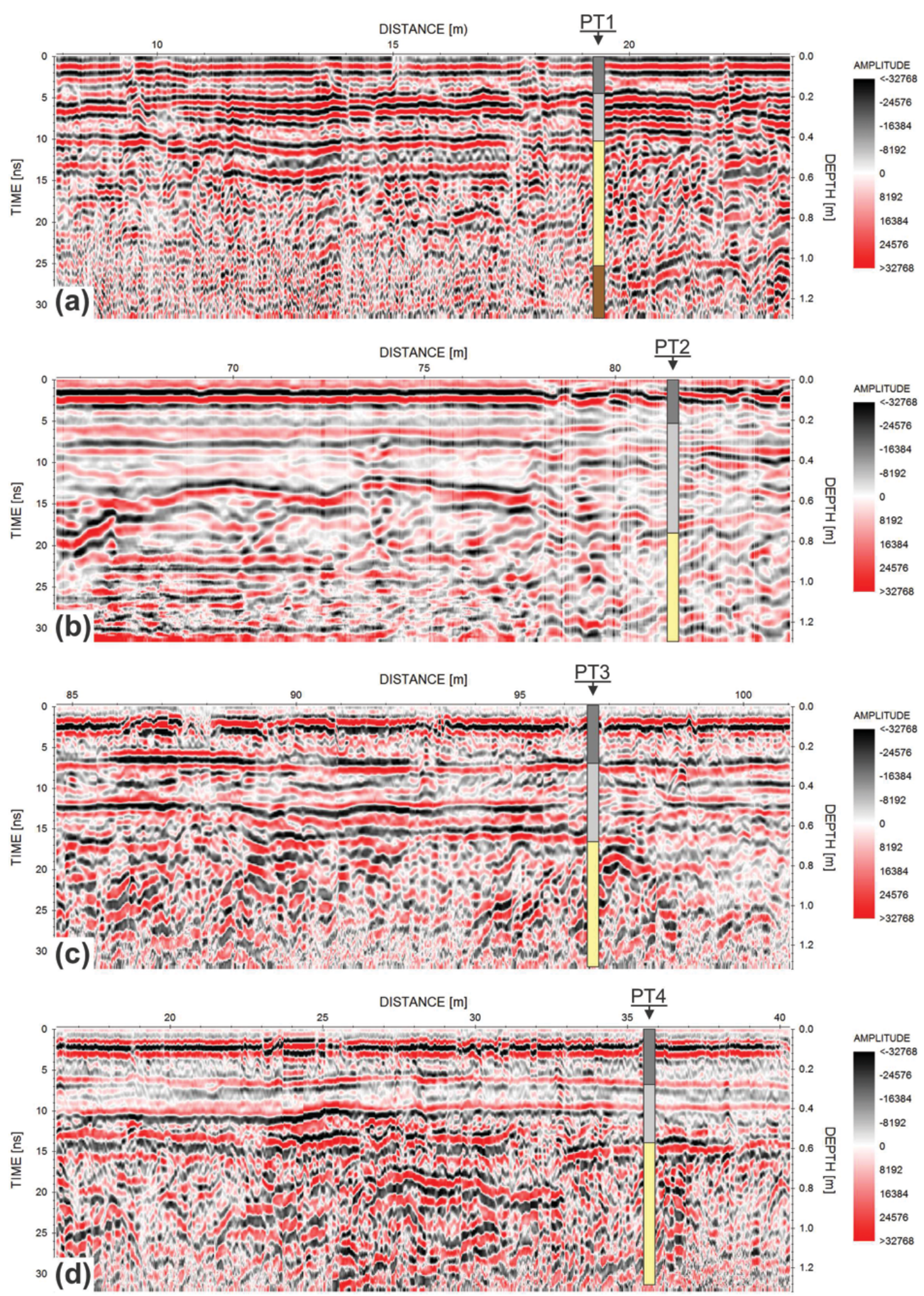

$\square$ concrete slab

$\square$ macadam (gravel)

fine to medium sand

silty sand

Figure 5 - GPR sections with geological and/or geotechnical information superimposed. (a) L1 with PT1. (b) L2B with PT2. (c) L2C with PT3. (d) L2E with PT4. 

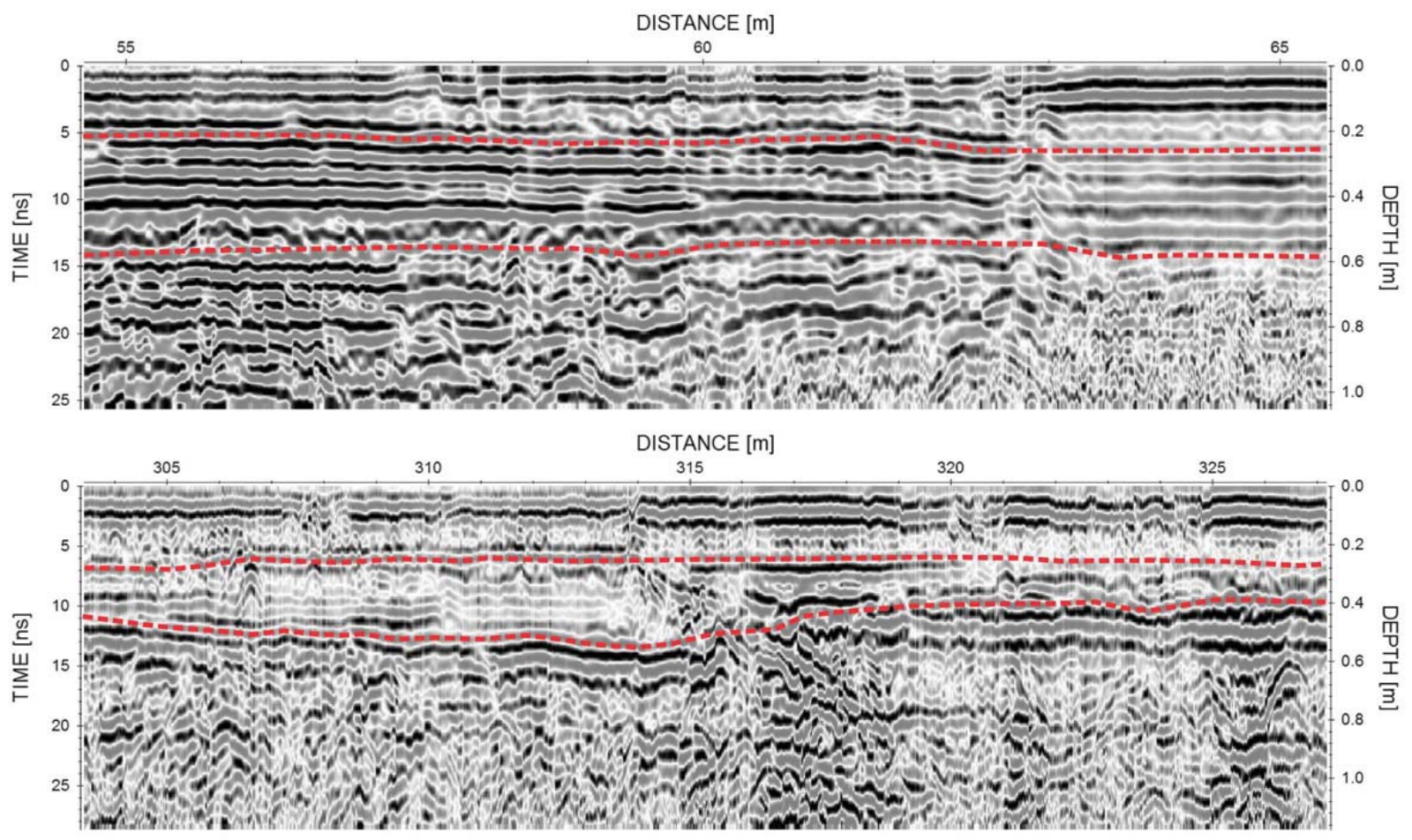

-n-- Continuous reflectors related to geotechnical and geological interfaces

Figure 6 - Examples of GPR sections with reflection patterns characteristic of the geological and/or geotechnical interfaces present in the area.

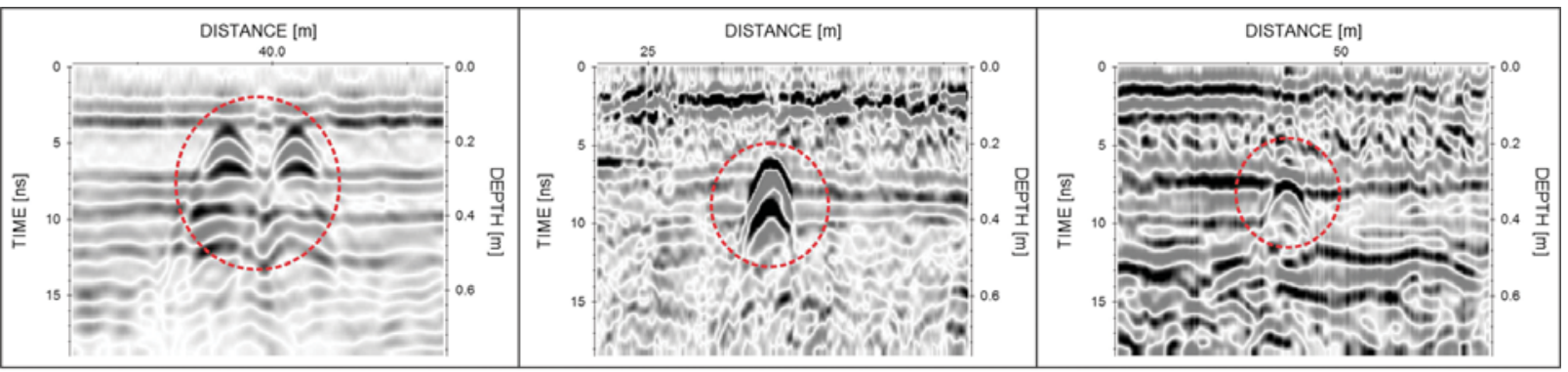

hyperbolic anomalies related to interference in subsurface

Figure 7 - Examples of GPR sections with hyperbolic reflection patterns (diffractions) related to interferences (pipes and/or stones) present in the pavement.

uses data from the picking to generate an interpretive model with the adjusted depths (Fig. 8).

As the coating showed a constant speed horizontally, its thickness was calculated at all traces of the profiles. These data enabled the creation of a histogram of the frequency distribution of coating thickness at each point of the pavement investigated (Fig. 9). The analysis shows that the histogram of the concrete coating ranges from $19 \mathrm{~cm}$ to $32 \mathrm{~cm}$, with a mean of $25 \pm 1.8 \mathrm{~cm}$. The values obtained confirm that the plates of rigid pavement of the aircraft manuever runway of Santos Dumont Airport, are within international standards (12.5 to $30 \mathrm{~cm}$ ) for general aviation airports (Kohn \& Tayabji, 2003).

\section{CONCLUSIONS}

The geophysical investigations with GPR enabled the lineation of continuous reflectors associated with geotechnical interfaces (thickness of concrete slab and macadam/gravel base) and geological (sand and embankment).

The results confirmed the efficiency of the antennas of $250 \mathrm{MHz}$ and $700 \mathrm{MHz}$ to measure the thickness of layers of concrete pavement at aircraft runway of Santos Dumont Airport. 

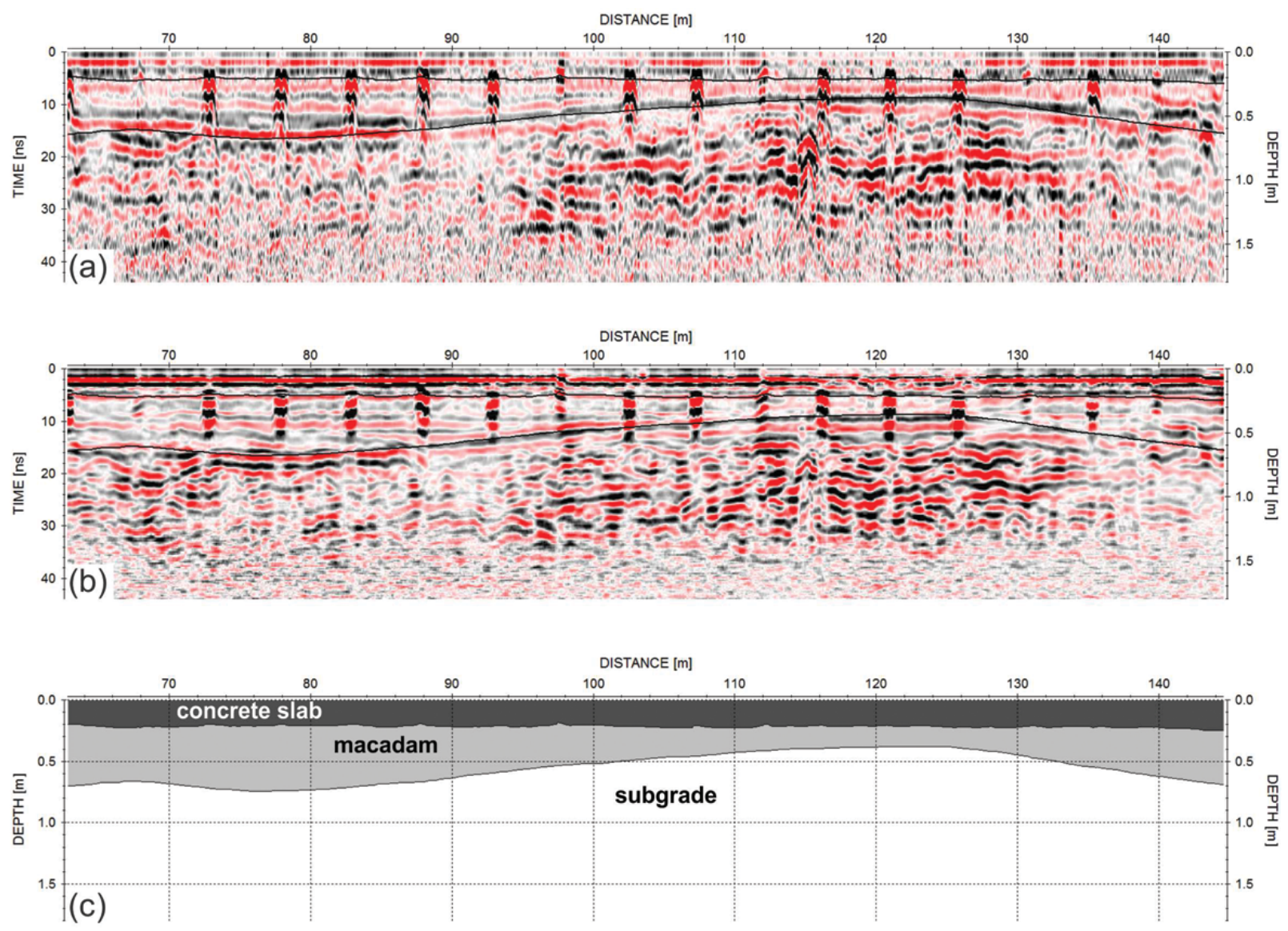

Figure 8 - GPR sections of L2E, obtained with antennas of (a) $250 \mathrm{MHz}$ and (b) $700 \mathrm{MHz}$, with geotechnical interfaces model superimposed. (c) Geological and geotechnical model obtained after the interpretation of the GPR sections.

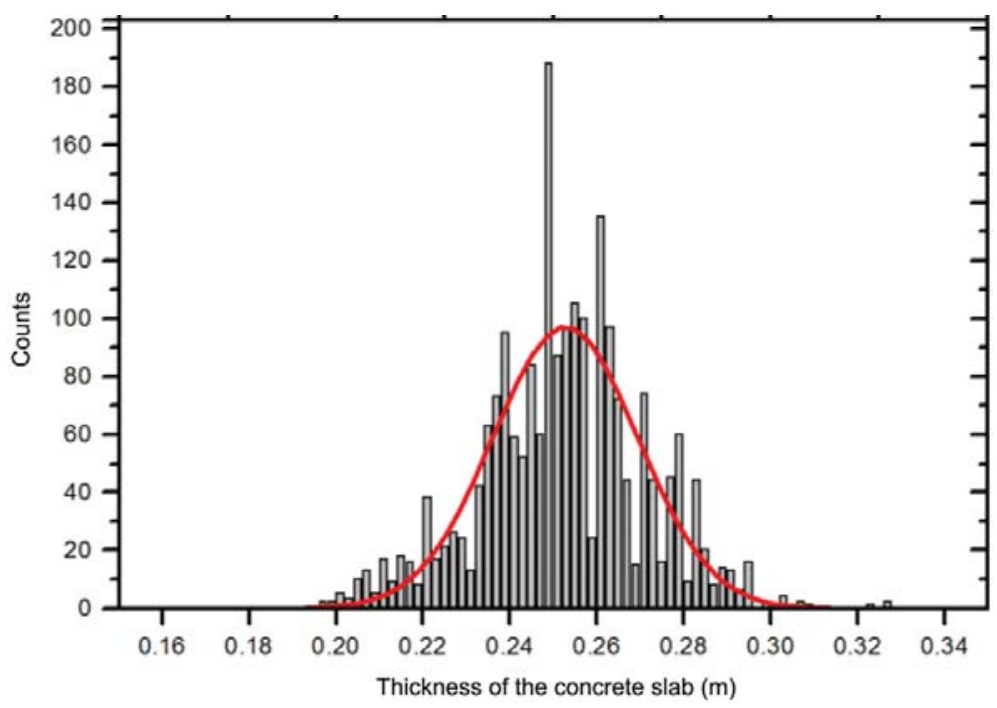

Figure $\mathbf{9}$ - Histogram of frequency distribution of concrete pavement thickness obtained with the GPR data from the Santos Dumont Airport. It is evident a Gaussian distribution with a mean at $0.25 \mathrm{~m}$. 


\section{ACKNOWLEDGMENTS}

The authors are thankful to the staff of INFRAERO of Santos Dumont Airport by the logistical support during the research.

\section{REFERENCES}

ANNAN AP. 2001. Ground penetration radar. Workshop notes. Sensors \& Software, Inc., Internal Report, 197 pp.

BARRILEV \& PUCINOTTIR. 2005. Application of radar technology to reinforced concrete structures: a case study. NDT \& E International, 38(7): 596-604.

BERNUCCI LP, MOTTA LM, CERATTI JA \& SOARES JB. 2006. Pavimentação asfáltica: formação básica para engenheiros. Abeda/Petrobras, Rio de Janeiro, 504 pp.

CHANG CW, LIN CH \& LIEN HS. 2009. Measurement radius of reinforcing stell bar in concrete using digital image GPR. Construction and Building Materials, 23(2): 1057-1063.

DNIT - Departamento Nacional de Infraestrutura de Transportes. 2006. Manual de Pavimentação. Diretoria de Planejamento e Pesquisa, Coordenação Geral de Estudos e Pesquisa, Instituto de Pesquisas Rodoviárias. 3 ed., Rio de Janeiro-RJ, 274 pp.

GOMES AFSS. 2008. Tecnologia aplicada à avaliação das estruturas dos pavimentos aeroportuários. Specialization Paper, Publicação E-TA006A/2008, Centro de Formação de Recursos Humanos em Transportes, Universidade de Brasília, Brasília/DF, 75 pp.

HUGENSCHMIDT J. 2002. Concrete Bridge Inspection with a Mobile GPR System. Construction and Building Materials, 16(3): 147-154.

HUGENSCHMIDT J \& MASTRANGELO R. 2006. GPR inspection of concrete bridges. Cement and Concrete Composites, 28(4): 384-392.

KOHN SD \& TAYABJI S. 2003. Best Practices for Airport Portland Cement Concrete Pavement Construction (Rigid Airport Pavement). Innovative Pavement Research Foundation, Report IPRF-01-G-002-1. 159 pp.
LAHOUAR S \& AL-QADI IL. 2008. Automatic detection of multiple pavement layers from GPR data. NDT \& E International, 41(1): 69-81.

LIMA-FILHO FP, MENEZES L, FREIRE RC, PORSANI JL \& MORAES JB. 2004. Aplicação do método GPR na identificação de causas de deformação no pátio de estacionamento do Aeroporto Internacional Pinto Martins em Fortaleza/CE. Revista de Geologia, Fortaleza, 17(2): 143156.

LOIZOS A \& PLATI C. 2007. Accuracy of pavement thicknesses estimation using different ground penetrating radar analysis approaches. NDT \& E International, 40(2): 147-157.

OLIVEIRA FHL \& NOBRE JR EF. 2008. Proposição de estratégias de manutenção de pavimentos aeroportuários baseadas na macrotextura e no atrito: estudo de caso do Aeroporto Internacional de Fortaleza. In: VII Simpósio de Transporte Aéreo. Proceedings... Rio de Janeiro, 178-182 - Tr. 367.

SANDMEIER KJ. 2011. REFLEXW Version 6.0, Windows 9x/NT/2000/ XP/7. Program for the processing of seismic, acoustic or electromagnetic reflection, refraction and transmission data. Software Manual. Karlsruhe, Germany, 532 pp.

SHAHIN MY. 1994. Pavement Management for Airports, Roads and Parking Lots. Chapman \& Hall, London, 450 pp.

TAC - Transportation Association of Canada. 1997. Pavement Design and Management Guide. Ralph Haas, coordinator. Ottawa, Canada, $389 \mathrm{pp}$.

TELFORD WM, GELDART LP \& SHERIFF RE. 1990. Applied Geophysics. 2 ed., Cambridge University Press, United Kingdom, 770 pp.

YODER EJ \& WITCZAK MW. 1975. Principles of Pavement Design. John Wiley \& Sons, New York, 711 pp.

Recebido em 5 outubro, 2012 / Aceito em 24 janeiro, 2014

Received on October 5, 2012 / Accepted on January 24, 2014

\section{NOTES ABOUT THE AUTHORS}

Welitom Rodrigues Borges. Degree in Geology from UFMT (2000), master's (2002) and doctorate (2007) degrees in Geophysics at IAG/USP. Consultant in GPR data processing in the agreement between the Unicamp and Brain Technology (2004/2006). Geophysical Consultant in the company Geopesquisa Geological Investigations (2006/2007). Consultant at GPR Company SIGEO - Integrated Solutions Geotechnology (2005/2007). Professor of Geophysics in CCA/UFES (2009). Currently Professor of Geophysics at IG/UnB. Develops research in the area of shallow geophysics applied to environmental, hydrogeological, geotechnical and forensic studies.

Luís Anselmo da Silva. Graduated in Electrical Engineering from the Universidade Católica de Petrópolis (1981). Specialization in Methodology of Technological Education (1994) and Masters in Civil and Environmental Engineering Program of Universidade Federal de Campina Grande (2002). Professor at the Instituto Federal de Educação, Ciência e Tecnologia de Mato Grosso. Currently, is developing doctorate at the Faculty of Technology, Universidade de Brasilia, in the area of geotechnics with emphasis in geophysics applied to rigid and flexible pavements. 
Luciano Soares da Cunha. Degree in Geology from Universidade de Brasília, MSc in Hydrogeology at Universidade Federal do Ceará. Currently, is an Adjunct Professor at the Institute of Geosciences of the UnB. Focuses research on the hydrogeology and shallow geophysical interface, applied to the environment. These researches are structured in the acquisition, processing and data integration in GIS and 3D modeling environments. Research in hydrogeology include hydrochemical studies of contamination and pollution of aquifers, groundwater flow modeling, vulnerability/risk models and estimates. The geophysical investigations involving electrical and electromagnetic methods in the time and frequency domain.

Raimundo Mariano Gomes Castelo Branco. Degree in Geology from the UFC, Specialization in Remote Sensing at INPE, Specialization in Gemology at UFOP, Master in Geochemistry and Geotectonics at USP and PhD in Geophysics and Remote Sensing at the University of Nantes in France. Currently, is an Associate Professor in the UFC Geology Department of the Science Center and participates in the Graduate Program LABOMAR; is part of Graduate course in Geosciences at UnB and the University of Cagliari in Italy. The main area of activity is linked to shallow geophysical investigation of coastal regions using geophysical methods. Conducts research in the area of non-seismic methods (EM, ER, Potential) applied to oil and gas. The geophysical investigations also involve electromagnetic methods on time domain and frequency domain (MT, TDEM, EM, GPR), electrical methods, geophysical well-logging and potential methods (GRAV, MAG) methods. Coordinator of several research projects along the major research funding agencies and companies such as FINEP, CNPq, BB, FUNCAP, MCT, MINC, MME - CPRM and PETROBRAS/CENPES.

Márcio Muniz de Farias. Degree in Civil Engineering at the UFC (1983), master's degree in Civil Engineering from PUC in Rio de Janeiro (1986) and PhD at the University of Wales at Swansea (1993). Professor at UnB since 1986, researcher of CNPq 1B, foreign researcher at Nagoya Institute of Technology (Japan), member of the scientific committee of the national magazine editorial Flooring (ABPv-Brazil), the binational Geotechnics (Brazil/Portugal), and international Road Materials and Pavement Design-RMPD (France), and reviewer for several international journals such as the Journal of Zhejiang University Science (China), Soils and Foundations (Japan), Computers and Structures (Europe). Experience in Geotechnical and Pavement areas, with emphasis on numerical methods and operates mainly in the topics: pavement, numerical analysis, constitutive models, dam and unsaturated soils. 